\title{
The Determinant Effect of ACFTA on Palm Oil Trade Between China and Indonesia
}

\author{
Muhammad Ridwan \\ Agriculture Information Institute (AII), Chinese Academy of Agricultural Sciences, \\ Haidian, Beijing 100081, China
}

\begin{abstract}
This research determines the effect of the ASEAN-China Free Trade Agreement (ACFTA) on the palm oil trade between China and Indonesia. This study discusses the analysis of the ACFTA and the effects on the economies of China and Indonesia. This research was analyzed using the gravity model and the analysis of the unit root test, lag selection criteria, co-integration, vector error correction model (VECM), long-run analysis test, short-run analysis test, and granger causality test using Eviews 8. The dependent variable used is palm oil export and independent variables include are Gross Domestic Product (GDP), Real Exchange Rate (RER), Foreign Direct Investment (FDI) and dummy variable (ACFTA) for both countries using data of 28 years (1990-2017). The case of China, the results shows that there is a long-run relationship between palm oil export with GDP, RER, FDI, and ACFTA and the palm oil export has a short-run relationship with GDP, FDI, and ACFTA, and palm oil export is showing causality with GDP, RER, FDI, ACFTA. Meanwhile, in the case of Indonesia, there is no long-run relationship between palm oil export with GDP, RER, FDI, and ACFTA but there is has a short-run relationship between palm oil export with GDP and palm oil export is showing causality with GDP, RER, and FDI. The implementation of ACFTA on palm oil trade between China and Indonesia have positive impacts on both countries and increase bilateral trade flows.
\end{abstract}

Keywords: China, Indonesia, ACFTA, Palm oil, Gravity model.

DOI: $10.7176 / \mathrm{JCSD} / 58-04$

Publication date: April $30^{\text {th }} 2020$

\section{Introduction}

Indonesia enhanced diplomatic relations with China in 1990, and the amount of trade between both countries had risen considerably after five years. There are some investment flows between China and Indonesia, but the volume is still relatively insignificant. At the current stage of development, the economy of both countries complements each other for trade between them (Atje \& Gaduh, 1999). Since 1991, trade relations between China and ASEAN members have been formed, and the inter-state economy has been developing for decades. The ASEAN economy has been active in the trade agreements such as the ASEAN-China Free Trade Agreement (ACFTA) over the past two decades, the purpose establishing of ACFTA is to create free trade by reducing and removing barriers, tariff of trade, increasing market, investment services, and ASEAN and China have increased their economic cooperation (Dianniar, 2013). The free trade agreement aims to dispose of some of the products, reduce the tariffs, and eliminate trade barriers between trade partners, China and ASEAN were eliminate their problems through ACFTA (Yean \& Yi, 2014).

Since the implementation of the ACFTA began, China became the third-largest trading partner for ASEAN. During 1995-2004, China's export to ASEAN member countries more than quadrupled from US \$ 10 billion to US \$ 44 billion China's. Meanwhile, export has increased from ASEAN countries to China, from US\$ 8,2 billion in 1995 to US\$ 42,2 billion in 2004 (Liu, 2007). The total trade between China and ASEAN countries totaled US $\$ 178$ and 18 billion in 2009 (Flick \& Kemburi, 2012). In 2009, China was reducing the tariff of ASEAN goods expected to 2,4 percent from 5,8 percent (Wu, 2011). At the end of 2009, taxes decreased to 0-5 percent for 18 commodities. In 2004 was eliminated tariffs barries all of the commodities. The Early Harvest Program (EHP) was initiated in 2004, focusing primarily on increasing bilateral tariffs for 600 agriculture products, including live animals, which mainly focused on reducing the taxes for 600 agricultural products, including live animals, fish, dairy products, meat, other animal products, vegetables, and fruits (Yang \& Martinez-Zarzoso, 2014). The principle of EHP is export-import between ACFTA members without a tariff where around 530 products include palm oil under the ASEAN-China EHP (Pambudi \& Chandra, 2006).

Palm oil is the world's most significant vegetable oil produced and traded (Faostat, 2018). Indonesian started planting palm oil in East Sumatra in 1991. Before 1974, the government of Indonesia reacted to the global market's elevated rates of palm oil, followed to create state-owned plantations. As a result, the areas increased from 295,000 ha in 1980 to 1.6 million ha and 4.2 million ha in 2000 to 6.07 million ha in 2006 (Abdullah \& Wahid, 2010). Indonesian oil palm area was 2.03 million ha in 1995 and 2000 became 3.18 million ha, an increase of more than 1 million ha (Amiruddin, 2003). In 2011 Indonesian oil palm plantations noted an area of 9.13 million ha, increasing to 10.75 million ha in 2015 or an increase of 25.80 percent. In 2016 it was estimated that the area oil palm plantations decreased by 0.15 percent from 2015 to 11.12 million ha (Guilhot, 2010). In 2018 the area of 
Indonesian palm oil had reached 14.03 million ha (Indonesia, 2009; Statistik, 2017).

The ACFTA improves the economy for China and ASEAN countries, and it has been going on for the past 20 years with mutual support among members. The ACFTA Framework Agreement on comprehensive economic cooperation provides legal instruments for trade, investment and economic relations for China and the ASEAN countries. Therefore, China and ASEAN member countries must be managed by policy. The government of China was trying to get positive results for China. ACFTA is claimed to be the largest FTA in the world based on population because of China and Indonesian large population in the world (JiangYu, 2011). In addition to increased economic benefits, China need support from ASEAN. Trade relations between China and Indonesia have the potential to improve their bilateral economic and by respecting the WTO procedures, economic relationships must be created for mutual benefit between countries (Booth, 2011).

The objectives of this study include the determinant effect of ACFTA on palm oil trade between China and Indonesia through variable perspectives included palm oil export, Gross Domestic Product (GDP), Real Exchange Rates (RER), Foreign Direct Investment (FDI), and Dummy Variables (ACFTA). Then, analyze the determinant effect of ACFTA for GDP, RER, FDI, and ACFTA on palm oil export between China and Indonesia. The purpose of this study is to use empirical work to analyze the effect of ACFTA on the palm oil trade between China and Indonesia using the scientific method by formulating a hypothesis. This study assesses the effect of trade in both countries through their financial variables. Furthermore, this research will show the implementation of ACFTA can improve the economic development of both countries. Data analysis based on this empirical analysis to appropriate values and data sources to be useful for future research on bilateral trade between China and Indonesia.

The rest of the paper paper is as follows: Section 2 presents an overview of the ASEAN-China Free Trade Agreement (ACFTA). Section 3 presents the overview of the palm oil export Indonesia to China. Section 4 describes the results and discussions of the study including the tests performed are the unit root test, lag selection criteria, Co-Integration, Vector Error Correction Model (VECM), Long-Run Analysis, Short-Run Analysis, and Granger Causality Test. Section 5 gives the conclusion of the study.

\section{ASEAN-China Free Trade Area (ACFTA)}

The ACFTA is an agreement between the ASEAN countries and China to create a free trade area by removing tariff and non-tariff barriers (Ardiyanti, 2015). Free trade is the exchange of goods and services between countries without constraints, but even if there are obstacles, the amount of tax must be minimal (Flick \& Kemburi, 2012). The ACFTA starts with the signing in Phnom Penh on 5 November 2002, and the implementation of ACFTA has begun in 2004 (Indriyani, 2016). The participants agreed to introduce an Early Harvest Program (EHP) that includes an agricultural and manufacturing package. By $1^{\text {st }}$ January 2006, trade between ASEAN and China would be under 0 percent (Supriana, 2013).

Various studies have shown that Indonesia was not optimal for implementation ACFTA. The monthly export data from January 1990-December 2011 are used to compare export from Indonesia to China after implementation ACFTA. Time series data are available, the results of this paper indicate Indonesia is not optimally utilized the ACFTA, China getting more benefits then Indonesia [22]. The main objective is to check whether ACFTA has the potential to benefit both parties. Pre-ACFTA trade, which continues to grow between ASEAN and China, shows that ACFTA will generate economic benefits for ASEAN and China, but unfavorable factors include limited substitution between ACFTA and import within-ACFTA (Park, 2007). This study uses an econometric model with a simultaneous equation system, the estimated parameter used is Two Stages Least Squares (2SLS). Policies in the ACFTA era 2010-2015 were carried out using simulations. The results state that the implementation of the ACFTA trade liberalization agreement is detrimental to the Indonesian economy (Ferrianta, Hanani, Setiawan, \& Muhaimin, 2012). ICRA Indonesia analyzes the benefits and challenges offered by ACFTA for the Indonesian economy, especially given the trade balance between Indonesia and China for the period 2005-2010. While the agreement has several positive implications, such as more significant product choices and lower product prices on the domestic market, more full access for Indonesian exporters to China's market requires the management of some of the adverse effects, especially for the industrial sector (Ginting, 2011). This article uses the model of gravity, a board of data comprising 20 measurements and calculated by the system of fixed effects. The unit-root test analysis and co-integration show the negative impact of the bilateral actual exchange rate on trade exports (Chit, 2008). This paper focuses on the effects of reducing trade barriers on investment. The results show that total investment in both ASEAN countries and China, particular emphasis on investment creation and the impact of transferring ACFTA, they find evidence the effect diversion of investments, some of the area that does not sign preferential agreements (Lakatos \& Walmsley, 2012). This paper explains whether the membership of the FDI flows in the Asia Pacific region in a bilateral or regional trade arrangement with an expanded gravity model has different impacts. The data panel consists of 30 countries from the Organization for Economic Development (OECD) and 43 host countries including 30 OECD countries and 13 non-OECD partners in Asia-Pacific Region from 1986 to 2000. Sectoral barriers to investment in manufacturing and services still exist and this is a significant obstacle for FDI in ASEAN. This study noted it is essential for considerable member countries such as Indonesia (Thangavelu 
\& Findlay, 2011).

Table 1. Tariff Reduction of Palm oil Trade between China and Indonesia

\begin{tabular}{|c|c|}
\hline Year & Palm Oil (\%) \\
\hline 2003 & 5 \\
\hline 2005 & 5 \\
\hline 2007 & 0 \\
\hline 2009 & 0 \\
\hline 2010 & 0 \\
\hline 2012 & 0 \\
\hline 2013 & 0 \\
\hline 2015 & 0 \\
\hline 2017 & 0 \\
\hline 2018 & 0 \\
\hline
\end{tabular}

${ }^{1}$ Source: ASEAN-China Tariff Reduction HS2007

Table 1 shows the tariff reduction of palm oil trade between China and Indonesia after implementation ACFTA and the tariff reduced to $0 \%$ in 2007. The implementation of ACFTA has reduced taxes of trade and will have a significant impact on trade. The agreement policy will affect the implementation of ACFTA, internal trade, domestic produce structure, export-import price and size (Li, 2014). Each member state may place up to 400 tariff lines (Sensitive Tracks) for which reduction or elimination of tariffs (Nasrudin \& Budiyanto, 2017). The taxes and exchange rates are two of the many variables affecting trade, to analyze the effect on the trade. According to economic theory, the taxes and exchange rates have a relationship with trade values (Markusen, Melvin, Maskus, \& Kaempfer, 1995).

\section{The Palm Oil Trade between China and Indonesia}

China is still a potential market for Indonesian agricultural products, especially palm oil export because China is in position four for palm oil consumption in the world 6,700 (1000 MT) and annual growth grate 3,36\% (Food \& Organization, 2019). China is the leading destination for Indonesian palm oil exports, the value of Indonesian palm oil export to China 3158827 tonnes in 2017 (Basiron, 2002).

Table 1. The Indonesia Palm Oil export quantity to China (1990-2017)

\begin{tabular}{|c|c|}
\hline Year & Palm Oil \\
\cline { 2 - 2 } & (tonnes) \\
\hline 1990 & 54926 \\
1991 & 166757 \\
\hline 1992 & 131427 \\
\hline 1993 & 51285 \\
\hline 1994 & 196409 \\
\hline 1995 & 167522 \\
\hline 1996 & 89181 \\
\hline 1997 & 401600 \\
\hline 1998 & 143519 \\
\hline 1999 & 342911 \\
\hline 2000 & 438084 \\
\hline 2001 & 365564 \\
\hline 2002 & 482810 \\
\hline 2003 & 800422 \\
\hline 2004 & 1083751 \\
\hline 2005 & 1354620 \\
\hline 2006 & 1758561 \\
\hline 2007 & 441099 \\
\hline 2008 & 1766957 \\
\hline 2009 & 2645356 \\
\hline 2010 & 2174410 \\
\hline 2011 & 2032844 \\
\hline 2012 & 2842112 \\
\hline 2013 & 2343399 \\
\hline 2014 & 2357263 \\
\hline 2015 & 3629608 \\
\hline & \\
\hline
\end{tabular}




\begin{tabular}{|c|c|}
\hline \multirow{2}{*}{ Year } & Palm Oil \\
\cline { 2 - 2 } & (tonnes) \\
\hline 2016 & 2664866 \\
2017 & 3158827 \\
\hline
\end{tabular}

${ }^{2}$ sources: Food and Agriculture Organization of the United Nation (FAOSTAT)

Table 2 shows that the Indonesian palm oil export quantity to China from 1990-2017. Indonesian palm oil export increased from 2004-2017 because of reduction of tax on palm oil export. There is a much rapid increase every year, especially in 2007 and 2008, their value was increased drastically from 2008 to 2017, this is because the taxed of palm oil export was eliminated to $0 \%$ of ACFTA.

\section{Materials and Methods}

4.1 Definition of Variables

The dependent variable used data palm oil export and independent variables includes data Gross Domestic Product (GDP), Real Exchange Rate (RER), Foreign Direct Investment (FDI), and dummy variable (ACFTA).

\subsection{Data Analysis}

The data variables used are GDP, RER, FDI, and the dummy variable (ACFTA) for China and Indonesia. The annual data was using 28 years from 1990-2017. Data palm oil export are obtained from FAOSTAT and Central Agency on Statistic (BPS-Statistics Indonesia). The GDP of China and Indonesia are obtained from the World Bank. The RER is obtained from FAOSTAT and the World bank (calculated by authors). The FDI is obtained from the World Bank. While the dummy variable is used to measure the impact of ACFTA on palm oil trade between China and Indonesia. Tariffs and exchange rates are two of the many variables affecting trade.

The methodology was used to find the relationship between variables. Analysis of data collected used econometric model, to the determinant effect of ACFTA on palm oil trade between China and Indonesia. First, make with the econometric model as regression. Then the first step is whether the data is stationary or not through the Unit Root Test, the determinant the number of lag was using lag selection criteria, then to determine the relationship between variables performed Co-Integration test using the Johansen test procedure, after that Vector Error Correction Model (VECM) test to determine the long-run relationship and short-run relationship between variables using wald test, and then Granger causality test to finding interconnection between variables.

\subsection{Empirical Model (Gravity Model)}

This analysis focus on the relationship between China and Indonesia after the implementation of ACFTA with a literature survey and data analysis through the empirical methodology. Furthermore, the Krugman theory model reflects the palm oil trade between China and Indonesia, contributing factors in both countries and the bilateral trade increased for this sector through ACFTA. Several previous studies using gravity model for analyzing a trade, determining the effects of East Asian free trade agreements on the trade using a gravity model to measure the strength of the three major Eastern Asian free trade agreements (ASEAN, ACFTA, and ASEAN-South Korea). Reassessing ACFTA on ASEAN manufacturing exports to China, use two models to examine and compare the impacts of ACFTA on the exportation of $\mathrm{P} \& \mathrm{C}$ and internal manufactured goods from the ASEAN-5 to China (Yean \& Yi, 2014). Every model is based on bilateral trade's basic gravity model. Using a panel of data 1995-2004 to analysis the influences and the potential of bilateral import trade flows in East Asia (Dan, 2008). Identification of the leading causes of trade flows used in explaining bilateral trade flows. The gravity model was used to analyze the impact on trade flows between ASEAN + 3 free trade agreement in the period 2000-2013 with panel information on GDP, GDP per capita, and distance between ASEAN member of trade and ASEAN world trade (Wang, Wei, \& Liu, 2010). The econometric model approach is a successful model analysis of international trade because of the empirical and consistency of the economic theory. The certification model can be applied with an FTA by variables that indicate whether the trading countries are included in the FTA (Thu \& Van Trung, 2015). The variables can be estimated whether the FTA has a significant effect on the trade or not. If the coefficient sign is positive and significant, it can be stated that the FTA has a positive impact on trade flows(Van Bergeijk \& Brakman, 2010).

The gravity equation has used to analyze trade between countries, although its success in the analysis of international trade has been explained in stages (Anderson, 2014). Obtain a gravity equation from a theoretical framework, the gravity model comes from the expenditure system, literature on theoretical models of gravity (Plummer, Cheong, \& Hamanaka, 2011). This study states that the gravity model used for the import-export demand of the trade (Hu \& van Marrewijk, 2013). Empirical estimates to find the effects of trade using the gravity equation. The gravity model assesses small countries and their trading partners have a more significant impact on international trade. International trade is a large part of overall economic activity and then reduces the cost of regional trade to international trade (Helpman \& Krugman, 1985).

The extended gravity model is used to support various trading theories, exchange rates, income, transportation 
costs, and a common language and its impact on trade and bilateral import-export relations (Sohn, 2005). On the effects of free trade between China and Indonesia using the Gravity Model founded by Tinbergen (1962) applying Newton's formula for bilateral trade. The gravity model, the most common dependent variable, is export and bilateral trade flows. While explanatory variables are the factors that show trade country demand, supply and barrier factors of trade flow between countries. The GDP per capita represents the level of income or purchase of the power of exporting and importing countries (Yan, 2007).

Based on (Yan, 2007) the basic gravity model as follows:

$$
\operatorname{Ln} \mathbf{X i j}=\beta 0+\beta 1 \ln (\mathbf{Y i Y j})+\beta 2 \ln \mathbf{D i j}+\mu \mathrm{ij}
$$

$X i j$ is the export value of country $i$ to state $j, Y i$ and $Y j$ are GDP, Dij is Foreign Direct Investment between country $i$ and country $j, \beta 0$ is constant, $\beta 1$ and $\beta 2$ is elasticity and $\mu i j$ is the error term. Therefore, the variables used in this study for empirical analysis using data from China and Indonesia such as GDP, Real Exchange Rates, Foreign Direct Investment (FDI), and dummy variables (ACFTA). The model used to analyze the determinant effect of ACFTA on palm oil trade between China and Indonesia is as follows:

$$
\begin{aligned}
& L n E X_{c j}^{t}=\beta 0+\beta 1 \ln \left(G D P_{c}^{t} G D P_{c}^{j}\right)+\beta 2 \ln R E R_{c j}+\beta 2 \ln F D I_{c j}+ \\
& \beta_{4} \text { IN_ACFTA A }{ }_{c j}^{t}+\mu_{c j}^{t}
\end{aligned}
$$

The evidence from the formula as follows:

$\operatorname{LnEX} X_{c j}^{t}$ as data palm oil export from Indonesia to China,

$G D P_{c}^{t} G D P_{c}^{j}$ as gross domestic product data of China and Indonesia,

$R E R_{c j}$ as the real exchange rate of China and Indonesia,

$F D I_{c j}$ as foreign direct investment data of China and Indonesia,

IN_ACFTA as dummy variables ( 0 for pre-ACFTA and 1 after ACFTA).

The value of 0 for pre-ACFTA and 1 after implementation ACFTA when the tariff becomes 0\% in 2007.

\section{Results and Discussions}

Methods are performed to know the relationship between the dependent and independent variables, following as palm oil export Indonesia to China, Gross Domestic Product (GDP), Real Exchange Rate (RER), Foreign Direct Investment (FDI), and dummy variables (ACFTA). The tests performed are the unit root test, Co-Integration, Lag Selection Criteria, Vector Error Correction Model (VECM), Long-Run Analysis, Short-Run Analysis, and Granger Causality Test.

\subsection{Unit Root Test}

The unit root test is used to test the assumption of a data time series stationary or not stationary. Stationary means there is constant in the data. The unit root test was used to test the stationarity palm oil export Indonesia to China, Gross Domestic Products (GDP), Real Exchange Rate (RER), Foreign Direct Investment (FDI), and ACFTA (Dummy) for both countries. We were used the Dickey-Fuller test to check if the data is stationary or nonstationary (Hendry and Juselius 2000). The unit root test such as:

1. At Level

2. At the 1st Difference

3. At the 2nd Difference

Null Hypothesis (H0) is the variable not stationary or has a unit root and Alternative Hypothesis (H1) is the variable stationery or does not have a unit root. If the unit root test shows the probability of less than 5 percent, it means the $\mathrm{H} 0$ is rejected and $\mathrm{H} 1$ is accepted or the variable stationery.

Table 3. Unit Root Test (ADF) China and Indonesia

\begin{tabular}{|l|c|c|}
\hline \multirow{2}{*}{ Variables } & \multicolumn{2}{|c|}{ Probability } \\
\cline { 2 - 3 } & At Level & First Differences \\
\hline Export & 0,4870 & 0,0000 \\
\hline GDP of China & 0,9024 & 0,0050 \\
\hline RER of China & 0,3951 & 0,0012 \\
\hline FDI of China & 0,7385 & 0,0000 \\
\hline ACFTA of China & 0,8304 & 0,0000 \\
\hline GDP of Indonesia & 0,8787 & 0,0000 \\
\hline RER of Indonesia & 0,3050 & 0,0003 \\
\hline FDI of Indonesia & 0,0890 & 0,0000 \\
\hline ACFTA of Indonesia & 0,8304 & 0,0000 \\
\hline
\end{tabular}

The table 3 shows that the unit root test results all of the variables such as palm oil, GDP, RER, FDI, and ACFTA for both countries. The variables not stationary at the level because the probability shows that more than 5 percent, but when converting into first difference all of variables are stationary. If all of variables stationary at 
first difference, Johansen test should be chosen for the co-integrating test. The first, we should know the lag of test (lag selection criteria) for Co-integration test.

\subsection{Lag Selection Criteria}

VAR Lag Order Selection Criteria

Table 4. Lag Selection Test of China

Endogenous variables: LNEXPORT LNGDP LNRER LNFDI DUMMY

Exogenous variables: $\mathrm{C}$

Date: 11/26/19 Time: 17:44

Sample: 19902017

Included observations: 25

\begin{tabular}{|c|c|c|c|c|c|c|}
\hline Lag & LogL & LR & FPE & AIC & SC & HQ \\
\hline 0 & -1501.285 & NA & $1.48 \mathrm{e}+46$ & 120.5028 & 120.7465 & 120.5704 \\
\hline 1 & -1453.584 & 72.50485 & $2.53 \mathrm{e}+45$ & 118.6867 & 120.1494 & 119.0924 \\
\hline 2 & -1414.057 & 44.27087 & $1.04 \mathrm{e}+45$ & 117.5245 & 120.2061 & 118.2683 \\
\hline 3 & -1305.951 & $77.83611^{*}$ & $3.19 \mathrm{e}+42^{*}$ & $110.8761^{*}$ & $114.7765^{*}$ & $111.9579 *$ \\
\hline
\end{tabular}

* indicates lag order selected by the criterion

LR: sequential modified LR test statistic (each test at 5\% level)

FPE: Final prediction error

AIC: Akaike information criterion

SC: Schwarz information criterion

HQ: Hannan-Quinn information criterion

VAR Lag Order Selection Criteria

Table 5. Lag Selection Test of Indonesia

Endogenous variables: LNEXPORT LNGDP LNRER LNFDI DUMMY

Exogenous variables: $\mathrm{C}$

Date: 11/26/19 Time: 19:08

Sample: 19902017

Included observations: 25

\begin{tabular}{|c|c|c|c|c|c|c|}
\hline Lag & LogL & LR & FPE & AIC & SC & HQ \\
\hline 0 & -1421.013 & NA & $2.41 \mathrm{e}+43$ & 114.0811 & 114.3248 & 114.1487 \\
\hline 1 & -1367.399 & $81.49440^{*}$ & $2.56 \mathrm{e}+42^{*}$ & 111.7919 & $113.2545^{*}$ & 112.1976 \\
\hline 2 & -1351.391 & 17.92864 & $6.93 \mathrm{e}+42$ & 112.5113 & 115.1928 & 113.2550 \\
\hline 3 & -1304.160 & 34.00623 & $2.76 \mathrm{e}+42$ & $110.7328^{*}$ & 114.6332 & $111.8146^{*}$ \\
\hline
\end{tabular}

* indicates lag order selected by the criterion

LR: sequential modified LR test statistic (each test at 5\% level)

FPE: Final prediction error

AIC: Akaike information criterion

SC: Schwarz information criterion

HQ: Hannan-Quinn information criterion

Tables 4 and 5 show that the lag selection test of China and Indonesia. The lag selection criteria were used to determine the number of lags to be chosen in the co-integration model. Based on the results the maximum lag for the model would be 3 lag in the co-integration test for China and Indonesia.

\subsection{Co-Integration}

The co-integration theory is the innovation theoretical econometrics that has created among economists in the last decade. The co-integration test includes a dependent variable is palm oil export and independent variables are data of GDP, RER, FDI, and ACFTA.

Through the co-integration test, the results of the test can be interpreted through finding variables order. Null Hypothesis (H0) is there is no co-integration among variables and Alternative Hypothesis (H1) is there is cointegration among variables. If the probability value is less than 5 percent significance, the H0 is rejected. if the probability value greater than 5 percent significance, the $\mathrm{H} 1$ is accepted. 
Date: 11/26/19 Time: 17:53

Table 6. Co-Integration Test of China

Sample (adjusted): 19942017

Included observations: 24 after adjustments

Trend assumption: Linear deterministic trend

Series: LNEXPORT LNGDP LNRER LNFDI DUMMY

Lags interval (in first differences): 2 to 3

Unrestricted Cointegration Rank Test (Trace)

\begin{tabular}{|c|c|c|c|c|}
\hline Hypothesized & & Trace & 0.05 & \\
\hline No. of CE(s) & Eigenvalue & Statistic & Critical Value & Prob.** \\
\hline None & 0.985582 & 185.2376 & 69.81889 & 0.0000 \\
\hline At most $1 *$ & 0.817022 & 83.49560 & 47.85613 & 0.0000 \\
\hline At most 2* & 0.636398 & 42.73420 & 29.79707 & 0.0010 \\
\hline At most 3 & 0.535512 & 18.45350 & 15.49471 & 0.0174 \\
\hline At most 4 & 0.002073 & 0.049816 & 3.841466 & 0.8234 \\
\hline
\end{tabular}

Trace test indicates 4 cointegrating eqn(s) at the 0.05 level

* denotes rejection of the hypothesis at the 0.05 level

**MacKinnon-Haug-Michelis (1999) p-values

Unrestricted Cointegration Rank Test (Maximum Eigenvalue)

\begin{tabular}{|c|c|c|c|c|}
\hline Hypothesized & & Max-Eigen & 0.05 & \\
\hline No. of CE(s) & Eigenvalue & Statistic & Critical Value & Prob. ${ }^{* *}$ \\
\hline None $*$ & 0.985582 & 101.7420 & 33.87687 & 0.0000 \\
\hline At most 1 $*$ & 0.817022 & 40.76140 & 27.58434 & 0.0006 \\
\hline At most 2* & 0.636398 & 24.28070 & 21.13162 & 0.0174 \\
\hline At most 3 & 0.535512 & 18.40368 & 14.26460 & 0.0105 \\
\hline At most 4 & 0.002073 & 0.049816 & 3.841466 & 0.8234 \\
\hline
\end{tabular}

Max-eigenvalue test indicates 4 cointegrating eqn(s) at the 0.05 level

* denotes rejection of the hypothesis at the 0.05 level

**MacKinnon-Haug-Michelis (1999) p-values

Table 7. Co-Integration Test of Indonesia

Date: 11/26/19 Time: 19:12

Sample (adjusted): 19942017

Included observations: 24 after adjustments

Trend assumption: Linear deterministic trend

Series: LNEXPORT LNGDP LNRER LNFDI DUMMY

Lags interval (in first differences): 2 to 3

Unrestricted Cointegration Rank Test (Trace)

\begin{tabular}{|c|c|c|c|c|}
\hline Hypothesized & & Trace & 0.05 & \\
\hline No. of CE(s) & Eigenvalue & Statistic & Critical Value & Prob.** \\
\hline None $*$ & 0.866719 & 104.8385 & 69.81889 & 0.0000 \\
\hline At most $1 *$ & 0.727697 & 56.47146 & 47.85613 & 0.0063 \\
\hline At most 2 & 0.492560 & 25.25130 & 29.79707 & 0.1527 \\
\hline At most 3 & 0.310689 & 8.970238 & 15.49471 & 0.3681 \\
\hline At most 4 & 0.001695 & 0.040718 & 3.841466 & 0.8400 \\
\hline
\end{tabular}

Trace test indicates 2 cointegrating eqn(s) at the 0.05 level

* denotes rejection of the hypothesis at the 0.05 level

**MacKinnon-Haug-Michelis (1999) p-values

Unrestricted Cointegration Rank Test (Maximum Eigenvalue)

\begin{tabular}{|c|c|c|c|c|}
\hline Hypothesized & & Max-Eigen & 0.05 & \\
\hline No. of CE(s) & Eigenvalue & Statistic & Critical Value & Prob.** \\
\hline None $*$ & 0.866719 & 48.36702 & 33.87687 & 0.0005 \\
\hline At most 1 $*$ & 0.727697 & 31.22016 & 27.58434 & 0.0163 \\
\hline At most 2 & 0.492560 & 16.28106 & 21.13162 & 0.2089 \\
\hline At most 3 & 0.310689 & 8.929520 & 14.26460 & 0.2921 \\
\hline At most 4 & 0.001695 & 0.040718 & 3.841466 & 0.8400 \\
\hline
\end{tabular}

Max-eigenvalue test indicates 2 cointegrating eqn(s) at the 0.05 level

$*$ denotes rejection of the hypothesis at the 0.05 level

**MacKinnon-Haug-Michelis (1999) p-values 
Tables 6 and 7 show that the trace test and Maximum Eigenvalue test of China indicate 4 co-integrating at 5 percent level significance of trace test and 4 co-integrating at 5 percent level significance of maximum eigenvalue. In the case of Indonesia, the trace test indicates 2 co-integrating at 5 percent level significance of trace test and 2 co-integrating at 5 percent level significance of maximum eigenvalue. There is indicates that the relationship among variables is co-integrated. Then, we run to test the Vector Error Correction Model (VECM) to analyze the long-run and short-run relationships among the variables.

\subsection{Vector Error Correction Model (VECM)}

Based on the results of the cointegration test, there is indicates cointegrating among variables, it's meant to run the VECM test. The VECM test to indicate the long and short relationship between the dependent variable (palm oil export) and independent variables (GDP, RER, FDI, and ACFTA).

5.4.1 Long-Run Analysis

Long-Run Analysis has tested the palm oil export as the dependent variable and independent variables include GDP, RER, FDI, and ACFTA. Null Hypothesis (H0) is there is no long-run relationship among variables and Alternative Hypothesis (H1) is there is a long-run relationship among variables. When we have a result probability of less than 5\% is means $\mathrm{H} 0$ is rejected and $\mathrm{H} 1$ is accepted or there is a long-run relationship between the palm oil export with GDP, RER, FDI, and ACFTA.

Dependent Variable: D(LNEXPORT)

Table 8. Long-Run Analysis for China

Method: Least Squares

Date: 11/26/19 Time: 18:23

Sample (adjusted): 19942017

Included observations: 24 after adjustments

$\mathrm{D}(\mathrm{LNEXPORT})=\mathrm{C}(1) *($ LNEXPORT $(-1)+0.027691974124 *$ LNGDP $(-1)-$ $0.154649187241 * \operatorname{LNRER}(-1)-0.0374417853928 *$ LNFDI(-1) -

107111.463297*DUMMY(-1) - 1370678.0364 ) + C(2)*D(LNEXPORT(

$-2))+\mathrm{C}(3) * \mathrm{D}(\operatorname{LNEXPORT}(-3))+\mathrm{C}(4) * \mathrm{D}(\operatorname{LNGDP}(-2))+\mathrm{C}(5) * \mathrm{D}(\operatorname{LNGDP}($

$-3))+\mathrm{C}(6) * \mathrm{D}(\operatorname{LNRER}(-2))+\mathrm{C}(7) * \mathrm{D}(\operatorname{LNRER}(-3))+\mathrm{C}(8) * \mathrm{D}(\operatorname{LNFDI}(-2))+$

$\mathrm{C}(9) * \mathrm{D}($ LNFDI $(-3))+\mathrm{C}(10) * \mathrm{D}(\mathrm{DUMMY}(-2))+\mathrm{C}(11) * \mathrm{D}(\mathrm{DUMMY}(-3))+$ $\mathrm{C}(12)$

\begin{tabular}{|r|r|r|r|r|}
\hline & Coefficient & \multicolumn{1}{c|}{ Std. Error } & \multicolumn{1}{c|}{ t-Statistic } & \multicolumn{1}{c|}{ Prob. } \\
\hline $\mathrm{C}(1)$ & -0.191950 & 0.068736 & -2.792554 & 0.0163 \\
\hline $\mathrm{C}(2)$ & 0.547327 & 0.227264 & 2.408335 & 0.0330 \\
\hline $\mathrm{C}(3)$ & 0.717377 & 0.226926 & 3.161279 & 0.0082 \\
\hline $\mathrm{C}(4)$ & 0.015521 & 0.008875 & 1.748864 & 0.1058 \\
\hline $\mathrm{C}(5)$ & -0.014489 & 0.014887 & -0.973276 & 0.3496 \\
\hline $\mathrm{C}(6)$ & -0.001076 & 0.014715 & -0.073140 & 0.9429 \\
\hline $\mathrm{C}(7)$ & -0.004971 & 0.019506 & -0.254817 & 0.8032 \\
\hline $\mathrm{C}(8)$ & 0.030869 & 0.057890 & 0.533246 & 0.6036 \\
\hline $\mathrm{C}(9)$ & 0.809897 & 0.060121 & 13.47109 & 0.0000 \\
\hline $\mathrm{C}(10)$ & -152935.1 & 66697.04 & -2.292981 & 0.0407 \\
\hline $\mathrm{C}(11)$ & 17262.95 & 67291.67 & 0.256539 & 0.8019 \\
\hline $\mathrm{C}(12)$ & -17387.17 & 13341.85 & -1.303205 & 0.2170 \\
\hline R-squared & 0.991395 & Mean dependent var & & -60880.79 \\
Adjusted R-squared & 0.983508 & S.D. dependent var & 397535.4 \\
S.E. of regression & 51052.72 & Akaike info criterion & & 24.82596 \\
Sum squared resid & $3.13 \mathrm{E}+10$ & Schwarz criterion & & 25.41498 \\
Log likelihood & -285.9115 & Hannan-Quinn criter. & & 24.98223 \\
F-statistic & 125.6886 & Durbin-Watson stat & & 1.842484 \\
Prob(F-stas & 0.000000 & &
\end{tabular}

Prob(F-statistic)

0.000000 
Table 9. Long-Run Analysis for Indonesia

Dependent Variable: D(LNEXPORT)

Method: Least Squares

Date: 11/26/19 Time: 19:15

Sample (adjusted): 19942017

Included observations: 24 after adjustments

$\mathrm{D}(\mathrm{LNEXPORT})=\mathrm{C}(1) *($ LNEXPORT $(-1)+0.214643458402 * \operatorname{LNGDP}(-1)-$ $0.0864863284382 *$ LNRER(-1) + 1.87737295496*LNFDI(-1) -

617246.186566*DUMMY(-1) - 6150779.1586) + C(2)*D(LNEXPORT(

$-2))+\mathrm{C}(3) * \mathrm{D}(\operatorname{LNEXPORT}(-3))+\mathrm{C}(4) * \mathrm{D}(\operatorname{LNGDP}(-2))+\mathrm{C}(5) * \mathrm{D}(\operatorname{LNGDP}($

$-3))+\mathrm{C}(6) * \mathrm{D}(\operatorname{LNRER}(-2))+\mathrm{C}(7) * \mathrm{D}(\operatorname{LNRER}(-3))+\mathrm{C}(8) * \mathrm{D}(\operatorname{LNFDI}(-2))+$

$\mathrm{C}(9) * \mathrm{D}(\mathrm{LNFDI}(-3))+\mathrm{C}(10) * \mathrm{D}(\mathrm{DUMMY}(-2))+\mathrm{C}(11) * \mathrm{D}(\mathrm{DUMMY}(-3))+$ $\mathrm{C}(12)$

\begin{tabular}{|c|r|r|r|r|}
\hline & Coefficient & Std. Error & t-Statistic & Prob. \\
\hline $\mathrm{C}(1)$ & -0.742634 & 0.474133 & -1.566299 & 0.1433 \\
\hline $\mathrm{C}(2)$ & 2.044660 & 1.752309 & 1.166838 & 0.2659 \\
\hline $\mathrm{C}(3)$ & 3.870025 & 1.448374 & 2.671979 & 0.0203 \\
\hline $\mathrm{C}(4)$ & -0.156847 & 0.107002 & -1.465825 & 0.1684 \\
\hline $\mathrm{C}(5)$ & 0.256727 & 0.123815 & 2.073467 & 0.0603 \\
\hline $\mathrm{C}(6)$ & 0.105417 & 0.163561 & 0.644512 & 0.5314 \\
\hline $\mathrm{C}(7)$ & 0.383853 & 0.176725 & 2.172040 & 0.0506 \\
\hline $\mathrm{C}(8)$ & -0.745790 & 1.314151 & -0.567507 & 0.5808 \\
\hline $\mathrm{C}(9)$ & 1.309844 & 1.090285 & 1.201377 & 0.2528 \\
\hline $\mathrm{C}(10)$ & -635006.9 & 458209.1 & -1.385845 & 0.1910 \\
\hline $\mathrm{C}(11)$ & -221900.8 & 368518.8 & -0.602142 & 0.5583 \\
\hline $\mathrm{C}(12)$ & -153714.4 & 99090.24 & -1.551257 & 0.1468 \\
\hline
\end{tabular}

R-squared

Adjusted R-squared

S.E. of regression

Sum squared resid

Log likelihood

F-statistic

Prob(F-statistic)
0.624048 Mean dependent var

0.279425 S.D. dependent var

337454.6 Akaike info criterion

$1.37 \mathrm{E}+12$ Schwarz criterion

-331.2372 Hannan-Quinn criter.

1.810814 Durbin-Watson stat

0.161072
$-60880.79$

397535.4

28.60310

29.19213

28.75937

1.191884

Tables 8 and 9 show the interpretation of long-run analysis, the coefficient of $\mathrm{C}(1), \mathrm{C}(2), \mathrm{C}(3)$ indicates palm oil export as a dependent variable and others such as GDP, RER, FDI, and Dummy are independent variables. Furthermore, $\mathrm{C}(4), \mathrm{C}(5)$ indicates as GDP, C(6), C(7) indicates as RER, C(8), C(9) indicates as FDI and C(10), $\mathrm{C}(11)$ indicates as ACFTA. If the $\mathrm{C}(1)$ is a negative sign and significant at 5 percent it means there is a long-run relationship running from GDP, RER, FDI, and ACFTA to palm oil export. The case of China shows that C(1) is a negative sign and significant or there is a long-run relationship among variables. Otherwise, in the case of Indonesia shows that there is a negative sign but no significant or there is no long-run relationship among variables. 5.4.2 Short-Run Analysis

Short-run analysis to indicate the short relationship between the dependent variable (palm oil export) and independent variables (GDP, RER, FDI, and ACFTA). In the short run, the analysis was tested on the Wald test for the GDP, RER, FDI, ACFTA of China and Wald test for the GDP, RER, FDI, ACFTA of Indonesia. Null Hypothesis (H0) is there is no short-run relationship among variables and Alternative Hypothesis (H1) is there is a short-run relationship among variables. If the probability of chi-square is less than $5 \%$ the $\mathrm{H} 0$ is rejected and $\mathrm{H} 1$ is accepted or there is a short-run relationship among variables.

Table 10. Short-Run Analysis (Wald Test)

\begin{tabular}{|c|c|c|c|c|}
\hline \multirow{2}{*}{ Variables } & \multicolumn{2}{|c|}{ F-statistic } & \multicolumn{2}{c|}{ Probability of Chi-square } \\
\cline { 2 - 4 } & China & Indonesia & China & Indonesia \\
\hline GDP & 0.1463 & 0.1038 & 0.0051 & 0.0002 \\
\hline RER & 0.9188 & 0.1307 & 0,9024 & 0.1307 \\
\hline FDI & 0.0000 & 0.4386 & 0.0000 & 0.4134 \\
\hline ACFTA & 0.1100 & 0.3749 & 0.0514 & 0.3444 \\
\hline
\end{tabular}

Table 10 shows the wald test of China and Indonesia if the probability of chi-square is less than 5 percent which means the independent variables (GDP, RER, FDI, ACFTA) has a short-run relationship with palm oil export. In the case of China the GDP, FDI, and ACFTA have a short-relationship with palm oil export. Otherwise, 
In the case of Indonesia, only the GDP has a short-relationship with palm oil export.

\subsection{Granger Causality Test}

Granger Causality Test is used to determine causality between variables. The Granger causality test if the time series stationary. If the variable is not stationary at level, then the test will be stationary at first difference. We were tested palm oil export, GDP, RER, FDI, and ACFTA on the Granger causality test. Null Hypothesis (H0) is GDP, RER, FDI, and ACFTA does not cause palm oil export and Alternative Hypothesis (H1) is GDP, RER, FDI, and ACFTA has granger cause palm oil export. If the result shows a probability of less than $5 \%$ is means that (H0) is rejected and H1 is accepted or the GDP, RER, FDI, and ACFTA has granger cause palm oil export.

Table 11. Granger Causality test of China

Pairwise Granger Causality Tests

Date: $11 / 27 / 19$ Time: $16: 10$

Sample: 19902017

Lags: 1

\begin{tabular}{|c|c|c|c|}
\hline Null Hypothesis: & Obs & F-Statistic & Prob. \\
\hline LNGDP does not Granger Cause LNEXPORT & 27 & 0.86698 & 0.3611 \\
\hline \multicolumn{2}{|l|}{ LNEXPORT does not Granger Cause LNGDP } & 0.27792 & 0.6029 \\
\hline LNRER does not Granger Cause LNEXPORT & 27 & 8.59616 & 0.0073 \\
\hline \multicolumn{2}{|l|}{ LNEXPORT does not Granger Cause LNRER } & 0.66624 & 0.4224 \\
\hline LNFDI does not Granger Cause LNEXPORT & 27 & 0.60673 & 0.4436 \\
\hline \multicolumn{2}{|l|}{ LNEXPORT does not Granger Cause LNFDI } & 0.44986 & 0.5088 \\
\hline DUMMY does not Granger Cause LNEXPORT & 27 & 0.31555 & 0.5795 \\
\hline \multicolumn{2}{|l|}{ LNEXPORT does not Granger Cause DUMMY } & 5.64795 & 0.0258 \\
\hline LNRER does not Granger Cause LNGDP & 27 & 0.08244 & 0.7765 \\
\hline \multicolumn{2}{|l|}{ LNGDP does not Granger Cause LNRER } & 0.03003 & 0.8639 \\
\hline LNFDI does not Granger Cause LNGDP & 27 & 0.84420 & 0.3673 \\
\hline \multicolumn{2}{|l|}{ LNGDP does not Granger Cause LNFDI } & 3.94315 & 0.0586 \\
\hline DUMMY does not Granger Cause LNGDP & 27 & 0.54610 & 0.4671 \\
\hline \multicolumn{2}{|l|}{ LNGDP does not Granger Cause DUMMY } & 5.80931 & 0.0240 \\
\hline LNFDI does not Granger Cause LNRER & 27 & 1.37185 & 0.2530 \\
\hline \multicolumn{2}{|l|}{ LNRER does not Granger Cause LNFDI } & 0.83170 & 0.3709 \\
\hline DUMMY does not Granger Cause LNRER & 27 & 0.03453 & 0.8541 \\
\hline \multicolumn{2}{|l|}{ LNRER does not Granger Cause DUMMY } & 0.50493 & 0.4842 \\
\hline DUMMY does not Granger Cause LNFDI & 27 & 0.11170 & 0.7411 \\
\hline \multicolumn{2}{|l|}{ LNFDI does not Granger Cause DUMMY } & 0.16429 & 0.6888 \\
\hline
\end{tabular}

Pairwise Granger Causality Tests

Table 12. Granger Causality test of Indonesia

Date: $11 / 27 / 19$ Time: $16: 14$

Sample: 19902017

Lags: 1

\begin{tabular}{|c|c|c|c|}
\hline Null Hypothesis: & Obs & F-Statistic & Prob. \\
\hline LNGDP does not Granger Cause LNEXPORT & 27 & 0.17604 & 0.6785 \\
\hline \multicolumn{2}{|l|}{ LNEXPORT does not Granger Cause LNGDP } & 0.49117 & 0.4901 \\
\hline LNRER does not Granger Cause LNEXPORT & 27 & 0.00193 & 0.9653 \\
\hline \multicolumn{2}{|l|}{ LNEXPORT does not Granger Cause LNRER } & 5.58887 & 0.0265 \\
\hline LNFDI does not Granger Cause LNEXPORT & 27 & 0.12129 & 0.7307 \\
\hline \multicolumn{2}{|l|}{ LNEXPORT does not Granger Cause LNFDI } & 10.6376 & 0.0033 \\
\hline DUMMY does not Granger Cause LNEXPORT & 27 & 0.31555 & 0.5795 \\
\hline \multicolumn{2}{|l|}{ LNEXPORT does not Granger Cause DUMMY } & 5.64795 & 0.0258 \\
\hline LNRER does not Granger Cause LNGDP & 27 & 2.09413 & 0.1608 \\
\hline \multicolumn{2}{|l|}{ LNGDP does not Granger Cause LNRER } & 0.01955 & 0.8900 \\
\hline LNFDI does not Granger Cause LNGDP & 27 & 0.76577 & 0.3902 \\
\hline \multicolumn{2}{|l|}{ LNGDP does not Granger Cause LNFDI } & 1.07913 & 0.3092 \\
\hline DUMMY does not Granger Cause LNGDP & 27 & 0.36598 & 0.5509 \\
\hline \multicolumn{2}{|l|}{ LNGDP does not Granger Cause DUMMY } & 0.20460 & 0.6551 \\
\hline
\end{tabular}




\begin{tabular}{|c|c|c|c|}
\hline LNFDI does not Granger Cause LNRER & 27 & 5.34482 & 0.0297 \\
\hline LNRER does not Granger Cause LNFDI & & 2.18132 & 0.1527 \\
\hline DUMMY does not Granger Cause LNRER & 27 & 0.68851 & 0.4149 \\
\hline LNRER does not Granger Cause DUMMY & & 3.40045 & 0.0776 \\
\hline DUMMY does not Granger Cause LNFDI & 27 & 1.23364 & 0.2777 \\
\hline LNFDI does not Granger Cause DUMMY & & 2.35322 & 0.1381 \\
\hline
\end{tabular}

Tables 11 and 12 show the Granger causality test results for palm oil export for China and Indonesia. We assume that the null hypothesis will be rejected if the probability of less than 5 percent. The result shows the null hypothesis is rejected because the probability is less than 5 percent of GDP, RER, FDI, ACFTA is causality with palm oil export.

As the results of the Granger Causality test give some as follow:

1. The case of China

- Palm oil export is showing causality with ACFTA.

- RER is showing causality with Palm oil export.

- GDP is showing causality with FDI.

- GDP is showing causality with FDI.

2. The case of Indonesia

- Palm oil export is showing causality with FDI.

- Palm oil export is showing causality with RER.

- FDI is showing causality with RER.

Based on analysis using an econometric model, it was concluded that ACFTA has increased export-import activity between China and Indonesia. The GDP, FDI, RER, and ACFTA which contributed to national income both countries, because palm oil trade is leading Indonesia's total export, and it influences the economic development of both countries. Even though China received greater benefits than Indonesia on the trade. however, enhancing the trade relationship between China and Indonesia is needed to provides optimal benefits from ACFTA.

\section{Conclusions}

The existence of the ASEAN-China Free Trade Agreement (ACFTA) for Indonesia has a significant influence on Indonesia's palm oil exports to China. These results indicate that there is a difference in the value of Indonesia's palm oil exports to China after the implementation of ACFTA. Empirical results using the extended gravity model show that GDP, Real Exchange Rates, FDI are the main factors affecting the economic progress of China and Indonesia. The impact of ACFTA implementation can be shown in the VECM model.

Under the theory of free trade, the presence of ACFTA for the smooth running of their export and import activities. The full implementation of ACFTA on January 1, 2010, has abolished tariffs on 6,683 posts in 17 sectors but for palm oil export tariff reductions occurred in 2004 and the tariffs were 0 percent in 2007, creating free trade and strengthening relations between China and Indonesia, especially palm oil trading. The Indonesian consumers to get benefit from buying cheap products from China and China exports of agriculture products from Indonesia such as palm oil and to grow to invest in Indonesia's infrastructure.

To analyze trade relations between China and Indonesia after the implementation of ACFTA and show the trade flows of associations in both countries, this study uses an empirical study using the extended gravity model. Empirical results using the extended gravity model shows that GDP, Real Exchange Rates, FDI are the main factors affecting the economic progress of China and Indonesia. The impact of ACFTA implementation can be shared in the VECM model. It is expected that the standard gravity variable has a static significance.

In the case of China, the results show a positive and significant long-run relationship between palm oil export with GDP, RER, FDI, and ACFTA. The development of China's economy is classified as rapid, the demand has also increased China's energy. Total China's energy consumption has the second-highest in the world. China is implementing the B5 program or 5 percent biodiesel mixture with diesel, the biodiesel in China has the potential to increase exports of Indonesian palm products because the price of palm oil cheaper. China can get greater profits because the lower price of palm oil, therefore will be increasing their GDP. In addition, China had investments in Indonesia such as infrastructure which is mostly the investments in Indonesia under China's control. The implementation of ACFTA, China can increase exports of Indonesian palm oil without taxes, so that China gets a lot of benefits besides the cheap price of palm oil, also does not need paying tax. Other than that, results show that there is a short-run relationship between palm oil exports with GDP, FDI, and ACFTA. The presence of ACFTA for China explains causality in several variables such as Palm oil export is showing causality with ACFTA, RER is showing causality with Palm oil export, GDP is showing causality with FDI, and GDP is showing causality with FDI, indicating that the independent variable promotes economic development.

In the case of Indonesia, the results show a positive impact, there is a short-run relationship between palm oil exports with GDP, but there is no short-run relationship with RER, FDI, and ACFTA. The results show that there 
is no long-run relationship running from palm oil exports with GDP, RER, FDI, and ACFTA. Indonesia feels the trade between Indonesia and China is not balanced. It means through ACFTA, imports of goods from China are greater than exports of Indonesian commodities to China. The government of China also has policies about limit imports from other countries. In addition, Indonesian palm oil products compete with soybean oil products from the USA, China as consumers of these two types of commodities. One of the reasons that short-run trade exists is because the export demand of China was increased, because the effects of the trade with USA, which is China reduced soybean export from the USA and replaced with palm oil, and the demand was increased for Indonesian palm oil export to China. But when the trade between China and the USA is stable, China will be reduced palm oil exports from Indonesia, we can say there is a short-run relationship. Actually the Palm oil exports increased Indonesian GDP when China increases exports of palm oil it will be increase GDP of Indonesia also. In addition, the presence of ACFTA for Indonesia explains causality in several variables such as palm oil export is showing causality with FDI and RER, and FDI is showing causality with RER. In general, high-income countries show a positive effect for long-run and short-run relationships and low-income countries will have a negative in long relationship or short relationship and this theory is also reflected in the trade relations between China and Indonesia.

This estimation aims to find the effects of variables on the trade between China and Indonesia. The variables have different effects which mean that enhancement on trade flows is still different between China and Indonesia. Besides, China and Indonesian palm oil trade have got benefits and since the implementation of ACFTA increased bilateral trade flows. It can be concluded that both countries have a positive impact on the palm oil trade.

There are suggestions to strengthen the relations between China and Indonesia, especially for the palm oil trade. The Indonesian government should discuss with China to replace soybean oil with palm oil. This is related to the trade that occurred between the USA and China. Thus, there are opportunities for the growth of Indonesia's palm oil exports to China. China applies taxed imports on soybean products from USA. On the other hand, China does not need taxed imports from Indonesia because of the ACFTA agreements. Since the ACFTA started in 2004, this agreement makes trade relations between China and Indonesia complementary to the palm oil trade. When the China financial crisis in 2008, China was still the main palm oil consumer and the demand increases for Indonesian palm oil exports to China, especially when the implementation ACFTA in 2007 which reduced a tax to $0 \%$, then palm oil trade between China and Indonesia increased dramatically.

\section{References}

Abdullah, R., \& Wahid, M. B. (2010). World palm oil supply, demand, price, and prospects: focus on Malaysian and Indonesian palm oil industry. Malaysian Palm Oil Board Press. Malaysia.

Amiruddin, M. N. (2003). Palm oil products exports, prices and export duties: Malaysia and Indonesia compared. Oil Palm Industry Economic Journal, 3(2), 15-20.

Anderson, J. E. (2014). Trade, Size, and Frictions: The Gravity Model. Retrieved August, 29, 2015.

Ardiyanti, A. (2015). The Impact of ASEAN Free Trade Agreement on ASEAN Members' Export. Research Paper of International Institute of Social Studies.

Atje, R., \& Gaduh, A. B. (1999). Indonesia-China economic relations: an Indonesian perspective. Centre for Strategic and International Studies Working Paper, Jakarta: CSIS, available at http://www. csis. or. id/working_paper_file/1, 3 .

Basiron, Y. (2002). Palm oil and its global supply and demand prospects. Oil palm industry economic journal, 2(1), 1-10.

Booth, A. (2011). China's economic relations with Indonesia: Threats and opportunities. Journal of Current Southeast Asian Affairs, 30(2), 141-160.

China's Ministry of Commerce. 2019. Http://english.mofcom.gov.cn/

Chit, M. M. (2008). Exchange rate volatility and exports: Evidence from the ASEAN-China Free Trade Area. Journal of Chinese Economic and Business Studies, 6(3), 261-277.

Dan, W. U. (2008). Bilateral Import Trade Flows and Trade Potentialities of East Asia: Empirical Study by Trade Gravity Model [J]. Journal of International Trade, 5.

Dianniar, U. (2013). The Impact of Free Trade Agreements on Indonesia's Agricultural Trade Flows: An Application of the Gravity Model Approach. Unpublished Master Thesis. The Hague, the Netherlands.

FAOSTAT. Crop Production Data (Rome: Food and Agricultural Organization of the United Nations, 2016.

FAOSTAT. Crop Production Data (Rome: Food and Agricultural Organization of the United Nations, 2016).

Ferrianta, Y., Hanani, N., Setiawan, B., \& Muhaimin, W. (2012). Impact of Trade Liberalization Asean-China Free Trade Area (ACFTA) on the Performance of Indonesia Maize Economy. Journal of Basic and Applied Scientific Research, 2(7), 6801-6809.

Firdaus, A. H. (2011). Trade Performance and Impact of the Free Trade Area (FTA) ASEAN Plus Three against the Indonesian Economy. Institute Bogor Agriculture.

Flick, K. E., \& Kemburi, K. M. (Eds.). (2012). ASEAN-China Free Trade Area: Challenges, Opportunities and the Road Ahead (No. 22). S. Rajaratnam School of International Studies, Nanyang Technological University. 
Ginting, A. (2011). The impacts of ACFTA to Indonesia-China trade. ICRA Indonesia Comment, Jakarta.

Guilhot, L. (2010). Assessing the impact of the main East-Asian free trade agreements using a gravity model. First results. Economics Bulletin, 30(1), 282-291.

Helpman, E. and Krugman, P. (1985). Market Structure and Foreign Trade. MIT Press, Cambridge, MA.

Hu, S., \& van Marrewijk, C. (2013). An empirical analysis of the africa-china trade puzzle: the role of China's trade policies.

Indriyani, I. (2016). The Effect of ASEAN-China Free Trade Area (ACFTA) on Indonesia Export. Etikonomi, 15(2).

JiangYu, W. (2011). China and East Asian Regionalism. European Law Journal, 17(5), 611-629.

Lakatos, C., \& Walmsley, T. (2012). Investment creation and diversion effects of the ASEAN-China free trade agreement. Economic Modelling, 29(3), 766-779..

$\mathrm{Li}, \mathrm{L}$. (2014). The impact on Customs of the implementation of the ASEAN-China FTA. World Customs Journal, 8(1), 87-98.

Liu, Y. (2007). ASEAN and China: Managing Competition and Exploring Complementarities.

Markusen, James R., et all. International Trade Theory and Evidence. New York: McGraw-Hill, Inc., 1995.

Ministry of Agriculture Indonesia, 2018.

N. Mursitama, Tirta and Y. Arif, Ilham. 2012. (Chapter) Indonesia on "ASEAN-China Free Trade Area Challenges, Opportunities and the Road Ahead”. Singapore: S. Rajaratnam School of International Studies.

Nasrudin, N., \& Budiyanto, B. (2017). The Indonesian Agricultural Performances Under China-ASEAN Free Trade Area: Go Up or Go Down? Case of Agriculture Raw Material and Food Product. Jurnal Sosio Agribisnis, 2(2).

Pambudi, D., \& Chandra, A. C. (2006). The impacts of the ASEAN-China Free Trade Agreement on the Indonesian economy. Institute for Global Justice.

Park, D. (2007). The prospects of the ASEAN-China Free Trade Area (ACFTA): A qualitative overview. Journal of the Asia Pacific Economy, 12(4), 485-503.

Plummer, M. G., Cheong, D., \& Hamanaka, S. (2011). Methodology for impact assessment of free trade agreements. Asian Development Bank.

Setiawan, S. (2012). ASEAN-China FTA: Its Impact on Indonesia and China Exports. Bulletin of Scientific R \& D Trade (2), 1-27.

Sohn, C. H. (2005). Does the gravity model explain South Korea's trade flows?. The Japanese Economic Review, 56(4), 417-430.

Supriana, T. (2013). Comparing the Effects of CAFTA on Internal Trade of China and ASEAN Countries. Technology and Investment, 4(03), 10.

Thangavelu, S. M., \& Findlay, C. (2011). The impact of free trade agreements on foreign direct investment in the Asia-Pacific region. ASEAN, 1, 2010-29.

Thu, N. A., \& Van Trung, V. (2015). Assessing the Impact of ASEAN+ 3 Free Trade Agreements on ASEAN's Trade Flows: A Gravity Model Approach1. Mediterranean Journal of Social Sciences, 6(6), 394.

Van Bergeijk, P. A., \& Brakman, S. (Eds.). (2010). The gravity model in international trade: Advances and applications. Cambridge University Press.

Wang, C., Wei, Y., \& Liu, X. (2010). Determinants of bilateral trade flows in OECD countries: evidence from gravity panel data models. The World Economy, 33(7), 894-915.

Wu, C. (2011). Forging Closer Sino-Indonesia Economic: Relations and Policy Suggestions. Ritsumeikan International Affairs, 10.

Yan, C. H. L. T. (2007). The Static Trade Effects in China under CAFTA_Empirical Analysis Based on the Gravity Model [J]. Journal of International Trade, 5.

Yang, S., \& Martinez-Zarzoso, I. (2014). A panel data analysis of trade creation and trade diversion effects: The case of ASEAN-China Free Trade Area. China Economic Review, 29, 138-151.

Yean, T. S., \& Yi, A. K. J. (2014). Re-examining the Impact of ACFTA on ASEAN's Exports of Manufactured Goods to China. Asian Economic Papers, 13(3), 63-82.

Yean, T. S., \& Yi, A. K. J. (2014). Re-examining the Impact of ACFTA on ASEAN's Exports of Manufactured Goods to China. Asian Economic Papers, 13(3), 63-82. 